University of Michigan Law School

University of Michigan Law School Scholarship Repository

\title{
The Proposed Code of Legal Ethics for the American Bar Association
}

\author{
Henry M. Bates \\ University of Michigan Law School
}

Available at: https://repository.law.umich.edu/articles/1195

Follow this and additional works at: https://repository.law.umich.edu/articles

Part of the Legal Ethics and Professional Responsibility Commons

\section{Recommended Citation}

Bates, Henry M. "The Proposed Code of Legal Ethics for the American Bar Association." Mich. L. Rev. 6 (1908): 318-22.

This Response or Comment is brought to you for free and open access by the Faculty Scholarship at University of Michigan Law School Scholarship Repository. It has been accepted for inclusion in Articles by an authorized administrator of University of Michigan Law School Scholarship Repository. For more information, please contact mlaw.repository@umich.edu. 


\section{MICHIGAN LAW REVIEW}

PUALISHED MONTHLY DURING THE ACADEXIC YEAR, EXCLUSTVZ OF OCTOBEX, BY TH: LAW FACULTY OF THE UNIVERSITY OF MICHIGAN

suesoniption phior, 82.80 pen rean,

96 CENTE PIR MUMEER

JAMES H. BREWSTER, Editor

ADVISORY BOARD:

HARRY B. HUTCHINS

VICTOR H. LANE

HORACE L. WILGUS

Editorial Assistants, appointed by the Faculty from the Class of 1908:

WILIARD T. Barbour, of Michigan.

Paul T. Barkes, of Pennsylvaniz. Hergert W. Clars, of New Mexico. Clydr A. DrWitr, of Michigan.

Srzpuxx W. Dowser, of Wyoming.

Fraxx B. Fox, of District of Columbia.

Arthur F. Friemarax, of Colorado.

Harotd W. Haxzon, of Michigen.

Fraxe P. Hzusert, of Iowa.

Burns Hzare, of Michigan.
Wirfrax B. Hzwry, of Michigan.

Jozx C. HowelL, of Michigan.

WrLlisx B. JAuEs, of Ohio.

Fraxcis B. Krexry, of Michigan.

Ross F. Moorz, of Indiana.

Riley E. Morgay, of Kansas.

Ronert M. Sex, of Ohio.

Oliver Starr, of Indiana.

Marshall M. Uzi, of Michigan.

Jonx E. Wriner, of Pennsylvania.

\section{NOTE AND COMMENT}

The Proposed Code of Legal Ethics for the American Bar Association. -The effort of the American Bar Association to frame and adopt a code of legal ethics is deserving of more attention from American lawyers than it is receiving. The adoption of such a code has been under consideration for several years. In 1905 the Association at its annual meeting instructed its committee to report at the meeting to be held in the next year upon "the advisability and practicability" of the adoption of such a code. In pursuance of these instructions the committee reported that in its judgment the adoption of such a code was not only advigable, but highly important, and also that it was practicable.

Among. the reasons advanced to show the advisability of adopting canons of legal ethics were mentioned: the important part filled by the American lawyer in the government of his country; the fact that members of the bar are officers of the court and hence essential to the processes of justice, and (to quote), "A further reason why we report the advisability of canons of legal ethics being authoritatively promulgated arises from the fact that many men depart from honorable and accepted standards of practice early in their 
careers as the result of actual ignorance of, the ethical requirements of the situation. Habits acquired when professional character is forming are lasting in their effects. The 'thus it is written' of an American Bar Association code of ethics should prove a beacon light. * * *" The 1906 report was received, the committee was continued and directed to further report at the 1907 meeting. The 1907 report recommends among other things that the Association reprint Sharswood's Essay on Professional Ethics, and distribute copies thereof to each member of the Association requesting that the members examine the Sharswood reprint and the documents printed in the appendix to said report, and make suggestions to the committee; also that the committee be authorized to have the proposed canons of professional ethics drafted by May I, Ig08, and on or about that date to transmit a copy to each member of the Association.

Under date of November 29, 1907 , the committee sent out copies of the Sharswood essay, of its own report to the Igo7 meeting, and a letter asking that definite and concrete suggestions as to the proposed code be sent to the secretary, Mr. Lucien Hugh Alexander, 714 Arcade Building, Philadelphia. The documents sent out are a most interesting contribution to this important subject, and it is to be hoped that the efforts of the committee will lead to definite results.

The report of the committee to the Association in Ig07 shows that codes of ethics have already been adopted by the bar associations of the states of Alabama, Georgia, Virginia, Michigan, Colorado, North Carolina, West Virginia, Wisconsin, Maryland, Kentucky and Missouri. The bar associations of several other states have the adoption of similar codes under consideration at the present time, and in several states canons of legal ethics have been incorporated into the oath administered upon admission to the bar. The codes referred to have all been adopted since 1887 , from which it will be seen that this movement is of comparatively recent origin, and that it is gaining strength rapidly. It seems to the writer of this note that the Alabama Code, the inspiration of which will be found largely in Sharswood's Essay on Professional Ethics, and which was adopted mainly through the effort and energy of Col. Thomas Goode Jones, afterward Governor of Alabama and now United States Judge for the middle and northern districts of Alabama, on the whole, solves the problem more effectively than any of the others. The particular difficulty to be overcome would seem to be to devise a code sufficiently specific and definite to afford an actual guide to conduct without being prolix and too dogmatic. It may be said, indeed, that an explicit compliance with all that may be fairly said to be included in the oath administered to lawyers in several of the states would keep the lawyer well within proper limits of conduct, but the difficulty is that these oaths are couched in such general terms as unfortunately to seem but mere formalities to many persons, and to throw no light upon the very definite problems which sometimes arise on the borderland between right and wrong. The Alabama Code consists of some sixty-three sections, some of which might perhaps be smitted and others shortened without impairing the usefulness of the code as a whole. 
It would be impossible within brief enough compass to summarize this code. Suffice it to say that practically all of the vexed questions, such as defending one whom the advocate believes to be guilty, direct and indirect methods of advertising, testifying for one's client, control of the trial as between lawyer and client, the considerations which may enter into the determination of the amount of the lawyer's fees, contingent fees, and attitude toward the jury, are for the most part concisely and satisfactorily dealt with.

With reference to contingent fees the code reads (Sec. 51): "Contingent fees may be contracted for; but they lead to many abuses, and certain compensation is to be preferred." Section 50 enumerates six elements which are to be considered in fixing the fee, all of which will readily occur to any lawyer of experience. Section 38 is one which too many lawyers disregard at the present time. It reads as follows: "Attorneys should as far as possible avoid becoming either borrowers or creditors of their clients; and they ought scrupulously to refrain from bargaining about the subject-matter of the litigation so long as the relation of attorney and client continues." The substance of Section to cannot be too often impressed upon the bar. It reads as follows: "Nothing has been more potential in creating and pandering to public prejudice against lawyers as a class, and in withholding from the profession the full measure of esteem and confidence which belong to the proper discharge of its duties, than the false claim often set up by the unscrupulous in defence of questionable transactions, that it is the attorney's duty to do everything to succeed in his client's cause. An attorney owes entire devotion to the interest of his client, warm zeal in the maintenance and defense of his cause, and the exertion of the utmost skill and ability to the end that nothing may be taken or withheld from him save by the rules of law legally applied. No sacrifice or peril, even to the loss of life itself, can absolve from the fearless discharge of this duty. Nevertheless, it is steadfastly to be borne in mind that the great trust is to be performed within and not without the bounds of the law which creates it. The attorney's office does not destroy man's accountability to his Creator or lessen the duty of obedience to law and the obligation to his neighbor; and it does not permit, much less demand, violation of law or any manner of fraud or chicanery for the client's sake." This certainly is a much better view of the subject than that extrasrdinary one expressed by Lord Brougram when he said: "The advocate in the discharge of his duty knows but one person in all the world, and that person is his client. To save that client by all means and expedients, and at all hazards and costs to all persons, and among them himself, is his first and only duty; and in performing this duty he must not regard the alarm, the torments and destruction he may bring upon others; separating the duty of a patriot from that of an advocate, he must go on reckless of consequences, though it should be his unhappy lot to involve his country in confusion."

The Bar Association especially invites suggestions upon the recent development of the question as to how far a lawyer may go in protecting his client's interest, in that new kind of service resulting from the recent enormous growth of the power of corporations and trusts, and the efforts of nation and 
state to control and curb that power. Some of the difficult questions thus raised will readily. occur to all lawyers. For example, what may the loyal citizen-lawyer do to reduce the tax-roll of his corporation clients operating in many states? May he properly circumvent the Sherman and other anti-trust statutes, or the Inter-State Commerce Act? The honest lawyer may well think that with the Northern Securities decision, which it is his duty as an officer of the court to obey in letter and spirit, on the one hand, and his duty to his client, who cannot escape the irresistible tendency of modern business toward consolidation, on the other hand, he is placed in a most perplexing position. The committee's request on that head is as follows: "We also earnestly request $* * *$ you to give us the benefit of your advice crystallized into specific canons concerning the principles which should ever guide the lawyer true to his country, his client and himself, in accepting the retainers of individuals and corporations, and in representing or advising them, knowing that by virtue of the establishment of the relation of counsel and client it will be his duty within the scope of the retainer to guard by every honorable means and to the best of his ability and learning the legal rights of the client."

While the committee asked that suggestions be made to it through its secretary before January 15, 1908, it is hoped that those who have not already examined the report of the committee and made their suggestions may do so at once. Doubtless any suggestion of importance could still be incorporated into the committee's report. It can scarcely be doubted that the adoption of the Code would do much to reverse the direction of the stream of public opinion concerning our profession, an opinion which unfortunately, and perhaps not wholly without justification, has been increasingly unfavorable in recent years. True it is that rules and law cannot make bad men good, but no one of experience can doubt for a moment the force of the committee's argument that many lawyers almost imperceptibly grow into unethical practices through sheer ignorance as to what is right. Every teacher of law can recall many interviews with students about to enter practice, in which the student, with entire ingenuousness, assumes that sharp practice, amounting even to trickery, is a common and accepted means of attaining the lawyer's ends in the service of his client. The establishment of the code of conduct by an association carrying the great moral influence which the American Bar Association should have, would unquestionably afford guidance to young men about to enter or just entering the practice of their profession, and prevent many of them from going astray. That this whole matter is regarded as of vital importance by the best men at the bar may be reasonably inferred from the makeup of the American Bar Association's committee. It includes such names as Henry St. George Tucker, Chairman; Justice Brewer, of the United States Supreme Court; Judge J. M. Dickinson, President of the American Bar Association for the present year; William Wirt Howe, of Louisiana; James G. Jenkins, of Wisconsin, formerly judge of the United States Circuit Court; Judge Thomas Goode Jones, of Alabama; the Hon. Alton B. Parker, of New York; George R. Peck, of Illinois, formerly president of the American Bar Association, and Francis Lynde Stetson, of New York. 
It is a pleasure to-record the fact that the present reprint of Sharswood's Professional Ethics was published at cost by the publishers of the regular edition, Messrs. T. \& J. W. Johnson Co., of Philadelphia, and that that cost was generously borne by General Thomas H. Hubbard, of New York, a valued member of the committee.

H. M. B. 